\title{
ZE STUDIÓW NAD NAJSTARSZYM OSADNICTWEM WCZESNOŚREDNIOWIECZNYM NA POMORZU ZACHODNIM
}

\author{
STUDIES ON THE OLDEST EARLY MEDIEVAL SETTLEMENTS \\ IN WEST POMERANIA
}

\begin{abstract}
The issue of the earliest medieval settlement in West Pomerania continues to generate discussions in the context of its dating and spread to various regions. The latest growth in the number of new archaeological sources related to this issue necessitates a new approach to the process of formation thereof. An attempt at explaining the chronological relations of this settlement in the face of the latest ancient settlement is a separate issue.
\end{abstract}

Keywords: West Pomerania, settlement, early Middle Ages, chronology.

Złożoność zagadnienia początków rozwoju osadnictwa wczesnośredniowiecznego na Pomorzu Zachodnim, będącego jednym z ważniejszych zagadnień Słowiańszczyzny Zachodniej, jeszcze nie tak dawno spowodowana była specyfiką bazy źródłowej, w której śladowo pozyskane informacje archeologiczne stanowiły jeden z podstawowych elementów działania, a także sposobem postępowania badawczego nawiązującego zazwyczaj do założeń metodologii pozytywistycznej (przegląd badań: Historia Pomorza, t. 1, cz. 1 [red.] G. Labuda 1972). Nie bez znaczenia pozostawał system dawniej realizowanych badań, w których początki osadnictwa wczesnośredniowiecznego traktowano zazwyczaj okazyjnie przy realizacji zagadnień, gdzie z metodycznego punktu widzenia wymagane było ustosunkowanie się do interesującego nas problemu (Łęga 1930; Leciejewicz 1960, s. 307-392; Filipowiak 1966, s. 71-118). Innym, lecz nader ważnym elementem tego zagadnienia, nawiązującym do głęboko zakorzenionej, zwłaszcza w polskiej i niemieckiej literaturze archeologicznej, dyskusji o wykazaniu lub braku ciągłości kulturowej i osadniczej, inaczej określanej jako kontynuacja lub dyskontynuacja rozwoju spo-

* Instytut Archeologii i Etnologii Uniwersytetu Gdańskiego, ul. Bielańska 5, 80-851 Gdańsk, e-mail: henmach@amu.edu.pl. 
łecznego na przełomie starożytności i wczesnego średniowiecza, pozostawało częste wykorzystywanie śladów po owym osadnictwie przy próbie przeprowadzania korelacji między różnymi przedmiotami, tj. „kultury archeologicznej”, a podmiotami, tj. wspólnotą społeczną (etniczną), celem wyznaczenia siedzib Słowian i Germanów w czasie zazwyczaj między IV a VII w. (Żak 1985, s. 85-108; Machajewski 2001, s. 92-94).

$\mathrm{W}$ 2. połowie $\mathrm{XX}$ w. w studiach nad wczesnym średniowieczem nastąpiła wręcz radykalna przebudowa metodologiczna systemu badawczego (Łosiński 1981; 1990). Postępowała ona niemal równolegle z rozbudową katalogu źródeł archeologicznych, opracowywania przynajmniej ich części, ale także zastosowania nowych metod datowania (dendrochronologia, daty radiowęglowe) oraz podejmowania prób tworzenia nowszych narracji o dziejach społeczności z przełomu starożytności i wczesnego średniowiecza zamieszkującej basen Morza Bałtyckiego (Parczewski 1988; Dulinicz 2001, s. 17-26). Nie bez znaczenia dla tych czynności pozostawał dynamiczny rozwój badań na Pomorzu także nad schyłkiem osadnictwa starożytnego (Godłowski 1981; Machajewski 1992a; 1992b, s. 71-96; 2017, s. 273-292).

Nie ulega jednak wątpliwości, że postęp w badaniach nad pomorskim wczesnym średniowieczem był w najszerszym zakresie zasługą działalności naukowej profesora Władysława Łosińskiego, wybitnego badacza i znawcy średniowiecznej strefy basenu Morza Bałtyckiego. To za Jego sprawą, by przywołać tylko niektóre Jego osiągnięcia, obraz osadnictwa wczesnośredniowiecznego w dorzeczu Parsęty uznaje się na Pomorzu za teren pod względem archeologicznym najlepiej rozpoznany, a nakreślone tam reguły osadnictwa za reprezentatywne dla strefy nizinnego pasa nadmorskiej moreny dennej. Także wypracowany przez tego badacza schemat zmian sposobów wytwarzania wczesnośredniowiecznej ceramiki naczyniowej uznaje się za wzorcowy dla niemal całej południowej strefy basenu Morza Bałtyckiego (por. Łosiński 1972).

Przystępując do dyskusji nad problematyką najstarszego osadnictwa wczesnośredniowiecznego na Pomorzu Zachodnim zauważa się, że pomimo postępu badań i realizacji w ostatnim czasie różnego rodzaju badań terenowych, trudno jest uznać dotychczas pozyskane informacje za proporcjonalne w stosunku do stanu pierwotnego. Być może, że dotychczas rozpoznany obraz osadnictwa, zarówno w dobie u schyłku starożytności, jak i na początku wczesnego średniowiecza, jest najbardziej zbliżony do rzeczywistego w dorzeczu dolnej i środkowej Parsęty, gdzie przez wiele lat prowadzono intensywne badania terenowe (Łosiński 1972; 1982; Machajewski 1981, s. 26-37). Jednocześnie podejmowane w ostatnim czasie prace archeologiczne w różnych regionach Pomorza zaczynają dostarczać nowych informacji, powodując potrzebę dokonania weryfikacji w naszym wyobrażeniu o nakreślonym wcześniej obrazie rozmieszczenia najstarszych śladach osadnictwa wczesnośredniowiecznego. Przykładem jest rejon Czarnówka, pow. lęborski, gdzie w sąsiedztwie cmentarzyska społeczności skandynawskiej, funkcjonującego do 1. połowy VI w., 
miało znajdować się, według Sławomira Wadyla (2015, s. 49-51), także cmentarzysko z pochówkami z najwcześniejszych etapów wczesnego średniowiecza, przypadającego na VII-VIII w. według ujęcia Marka Dulinicza (2001), lub na czasy nieco wcześniejsze, VI-VII w., w ujęciu Władysława Łosińskiego (1982). Wnioski Sławomira Wadyla, niezależnie od przyjętego sposobu datowania na Pomorzu początków wczesnego średniowiecza, budzą pewne jednak zastrzeżenia w tym sensie, czy rzeczywiście wszystkie pochówki w Czarnówku uznane przez tego badacza za groby pochodzą z wczesnego średniowiecza, czy jednak przynajmniej ich części (np. obiekt R 183, R 331) łączyć nie należy z pochówkami jeszcze skandynawskimi, sąsiadującymi na tym cmentarzysku z grobami wczesnośredniowiecznymi (Wadyl 2015, mapa pod opaską). Możliwość zgłoszenia takiej wątpliwości wynika z faktu wyjątkowej zbieżności cech techniki wykonania ceramiki spotykanej w grobach skandynawskich i z początkowych etapów wczesnego średniowiecza (materiały z Czarnówka przechowywane w Muzeum w Lęborku znane mi z autopsji).

Najstarsze wczesnośredniowieczne osadnictwo Pomorza Zachodniego reprezentowane jest przez około 31 punktów osadniczych. $Z$ tej grupy 12 punktów badano w sposób wykopaliskowy, pozostałe 19 rozpoznano jedynie na podstawie wyników penetracji powierzchniowej. Podstawą włączenia punktu do rzeczonego katalogu były jedynie cechy techniczne odkrytej na nich ceramiki naczyniowej, odpowiadające cechom rodziny typów A lub typów A - B w ujęciu W. Łosińskiego i R. Rogosza (1983, s. 202-203; 1986, s. 13). W tym ujęciu zaliczono tu ceramikę ręcznie lepioną typu „Dziedzice” i ceramikę słabo górą obtaczaną zbliżoną do typu „Gołańcz" (por. Łosiński 1972, s. 35-36; Łosiński, Rogosz 1986, s. 13; Cnotliwy 1986, s. 148-151; Sikorski 1987, s. 298). Takie postępowanie wynika z braku możliwości określenia zazwyczaj techniki wykonania poszczególnych form naczyń, jakkolwiek ze względu na formę naczynia owe rodziny tworzą dość spójny zespół (por. Łosiński, Rogosz 1983, s. 203). Zdajemy sobie jednak sprawę z tego, że w odniesieniu zwłaszcza do zbiorów będących efektem jedynie przeprowadzonej penetracji powierzchniowej, takie założenie klasyfikacyjne może prowadzić do wyciągania mylących wniosków. Wynika to z faktu, że wspomniane dwie najwcześniejsze rodziny ceramiki współwystępują z rodzinami późniejszymi, niekiedy aż do X wieku. W związku z badaniami nad techniką wykonania ceramiki grupy dębczyńskiej, zwłaszcza z wydzieloną tam grupą II, typu 2, wydzieloną na przykładzie znalezisk pochodzących z dorzecza Parsęty, zauważa się także ewidentne jej podobieństwa do ceramiki typu „Dziedzice” (rodzina A - B), co może wywoływać kolejne nieporozumienia w jej datowaniu (por. Sikorski 1982, s. 247-249; Machajewski 1992a, s. 111-112).

W ujęciu techniki wykonania, niezależnie od wyżej zasygnalizowanych kwestii przyjmuje się, że naczynia rodziny $\mathrm{A}$ - B, ręcznie lepione i częściowo górą obtaczane, charakteryzują się wygładzonymi powierzchniami, niekiedy angobowanymi, z domieszką ostrokrawędzistą (granit, gruby żwir), przełomem dwubarwnym, bar- 
wie powierzchni zewnętrznej zazwyczaj brunatnej lub brązowej, wewnętrznej szarej lub ciemnobrunatnej (por. Sikorski 1986, s. 33-35; 1987, s. 284-290).

Podstawy datowania tych dwóch grup naczyń są nader ograniczone. Wynikają one z braku przekonywających wyznaczników chronologicznych i stratygraficznych. Również poszukiwane doń analogie, spotykane zazwyczaj w Meklemburgii (ceramika typu Sukow) i w Wielkopolsce (ceramika typu A), tylko ogólnie uzasadniają jej sytuowanie w najwcześniejszych odcinkach wczesnego średniowiecza (VI-VII w.) (M. Parczewski 2017, s. 62, ryc. 3). Gdyby jednak, zgodnie z sugestią Jana Żaka (1978, s. 111-112), przyjąć założenie, że na Pomorzu Zachodnim ceramika słabo obtaczana typu „Gołańcz” jest stosunkowo dobrze datowana na VII w., to ceramika typu „Dziedzice”, zapewne od niej starsza, musiałaby pojawić się na początku VII w. lub nawet jeszcze wcześniej (VI-VII w.). W tym ujęciu, akceptując tezę o odmienności formalnej i technicznej ceramiki rodziny A - B wobec klasycznej wczesnośredniowiecznej ceramiki typu praskiego, przyjmujemy założenie, że jest to ceramika najwcześniejsza w tradycji początków pomorskiego wczesnego średniowiecza, zapewne późniejsza od ceramiki praskiej, obrazująca po części lokalne cechy w technice wykonania (np. angobowanie, obmazywanie?) i w formie (przysadzistość naczyń) (por. Żak 1978, s. 115; Sikorski 1987, s. 279-280; Dulinicz 2001, s. 50-53).

Niewątpliwie ważnym elementem przy wyodrębnianiu i datowaniu ceramiki rodziny A - B pozostają wyniki badań nad ceramiką z wczesnej fazy okresu wędrówek ludów (IV w./V w.-V w./VI w.). Najpóźniejsze elementy osadnictwa starożytnego na Pomorzu Zachodnim, w postaci cmentarzysk skandynawskich typu Głuszyno - Czarnówko - Brzyno, skarbów typu „Karlino” i „Suchań”, znalezisk złotych naszyjników typu „Piotrowice”, najpóźniejszych złotych monet Anastazjusza I (491-518 r.) pochodzą z pierwszych dekad VI wieku. Rozpoczęcie jednak procesu rozpraszania się osadnictwa starożytnego na Pomorzu Zachodnim, jak się zdaje, rozpoczęło się już około połowy V w. lub nieco później, po czym pojawiły się tutaj jeszcze wcześniej wspomniane elementy kulturowe najwyraźniej reprezentujące tradycje skandynawskie (Machajewski 2012, s. 222; 2017, s. 273-292; Strobin, Machajewski 2017, s. 570-571). Jednocześnie wśród najpóźniejszej starożytnej ceramiki naczyniowej, spotykanej na osadach ze schyłku starożytności, ale i także na cmentarzyskach skandynawskich, odnotowuje się ceramikę o cechach technicznych przypominających ceramikę typu „Dziedzice”. Czy zatem owa zbieżność cech mogła być następstwem współwystępowania na tych samych obszarach, zwłaszcza w dorzeczu Parsęty i Łeby, skupisk osadniczych funkcjonujących u schyłku starożytności i na początku wczesnego średniowiecza, odzwierciedlających tradycje kulturowe wyrastające z rozwoju kontaktów wymiennych prowadzonych zwłaszcza między Skandynawią, Pomorzem a Wielkopolską? (por. Machajewski 2017, s. 288, ryc. 11).

Wydzielony, na podstawie tak dyskusyjnych przesłanek chronologicznych, zespół około 31 punktów osadniczych to osady nieobronne datowane na VI-VII w. 
(27 punktów), a także dwie dalsze osady nieobronne, jedno grodzisko i jedno cmentarzysko pochodzące z VII-VIII wieku (por. wykaz). Włączenie do tego katalogu grodziska z Białogardu, określanego niekiedy jako quasi-gród, i cmentarzyska z Czarnówka, założonych zapewne na początku VII w., reprezentujące na Pomorzu Zachodnim formy osadnicze odmienne wobec wcześniej spotykanych, podyktowane zostało potrzebą zasygnalizowania złożoności procesu formowania się najwcześniejszego osadnictwa wczesnośredniowiecznego, a jednocześnie trudnościami z ich datowaniem (Cnotliwy 1999, s. 74, ryc. 2; Łosiński 2008, s. 71; Wadyl 2015, s. 49-57).

Wszystkie dotychczas wydzielone punkty rozmieszczone były głównie w strefie nizinnego pasa moreny dennej w rejonie: Równiny Pyrzycko-Stargardzkiej, dolnej Odry, górnej Regi, środkowej i dolnej Parsęty oraz ostatnio także dolnej Łeby (ryc. 1). Możliwość poznania sposobu organizowania zabudowy na osadach otwartych na podstawie siedmiu częściowo rozpoznanych osadach (katalog - nr 5, 6, 7, $8,11,18,30)$ sprowadza się do uwagi, że były to osady o powierzchni od 0,3 do 1,0 ha, z dwoma odmiennymi sposobami rozplanowania. Pierwszy z nich to osady z zabudową rozmieszczoną wokół placu centralnego, o średnicy około $20 \times 30 \mathrm{~m}$, wyznaczonego przez obiekty zagłębione, o średnicy $3 \times 4$ m (ziemianki?) i naziemne (katalog - nr 6, 11, 18). Niekiedy zauważa się kilka placów centralnych, niewykluczone, że o odmiennym już czasie ich użytkowania (katalog - nr 10). Drugi sposób- to zabudowa gniazdowa o bezplanowym rozmieszczeniu obiektów (katalog - nr 7, 8, 30) (por. Łosiński 1982, s. 134-144; Dulinicz 2001, s. 165-175). Pierwszy z tych sposobów przypomina zabudowę spotykaną już na późnorzymskich osadach grupy dębczyńskiej z tą różnicą, że place na tych osadach były nieco większe $(30 \times 35 \mathrm{~m})$. Wyznaczone były jednocześnie przez regularnie rozmieszczone na jego obwodzie liczne ziemianki, budynki naziemne oraz skupiska palenisk (Machajewski 1992a, s. 128-130).

Zupełnie odmienny, co zrozumiałe, sposób zabudowy reprezentuje nieduże, nizinnie położone w rozlewiskach środkowej Parsęty, niekiedy nazywane wręcz quasi-grodem, grodzisko w Białogardzie założone prawdopodobnie na początku VII w. (Cnotliwy 1982, s. 15-21. Por. Łosiński 2008, s. 70, tab. 1) (katalog - nr 2). Zlokalizowano je na niewielkim wyspowatym wzniesieniu, zajmującym obszar około $3500 \mathrm{~m}^{2}$, położonym wśród wód i bagien. Owo wyniesienie, na jej styku z wodą, wygrodzono wałem o szerokości około $5,5 \mathrm{~m}$. Zbudowano także pomost drewniany otaczający przynajmniej pewien odcinek wału. Wielkość wnętrza grodziska mogła wynosić około $2200 \mathrm{~m}^{2}$. Wśród wielu grodzisk zachodniopomorskich podobny sposób lokowania i budowania umocnień pojawił się dopiero w VIII-IX wieku (np. Kędrzyno; Świelubie). Z czasem grodzisko w Białogardzie uległo wielu przebudowom.

Przywołanie w tym katalogu grodziska białogardzkiego znajduje uzasadnienie $\mathrm{z}$ racji nie tylko jego chronologii i sposobu budowy, wyjątkowego na tle pomorskiego wczesnego osadnictwa grodowego (por. W. Łosiński 1982), ale także rela- 


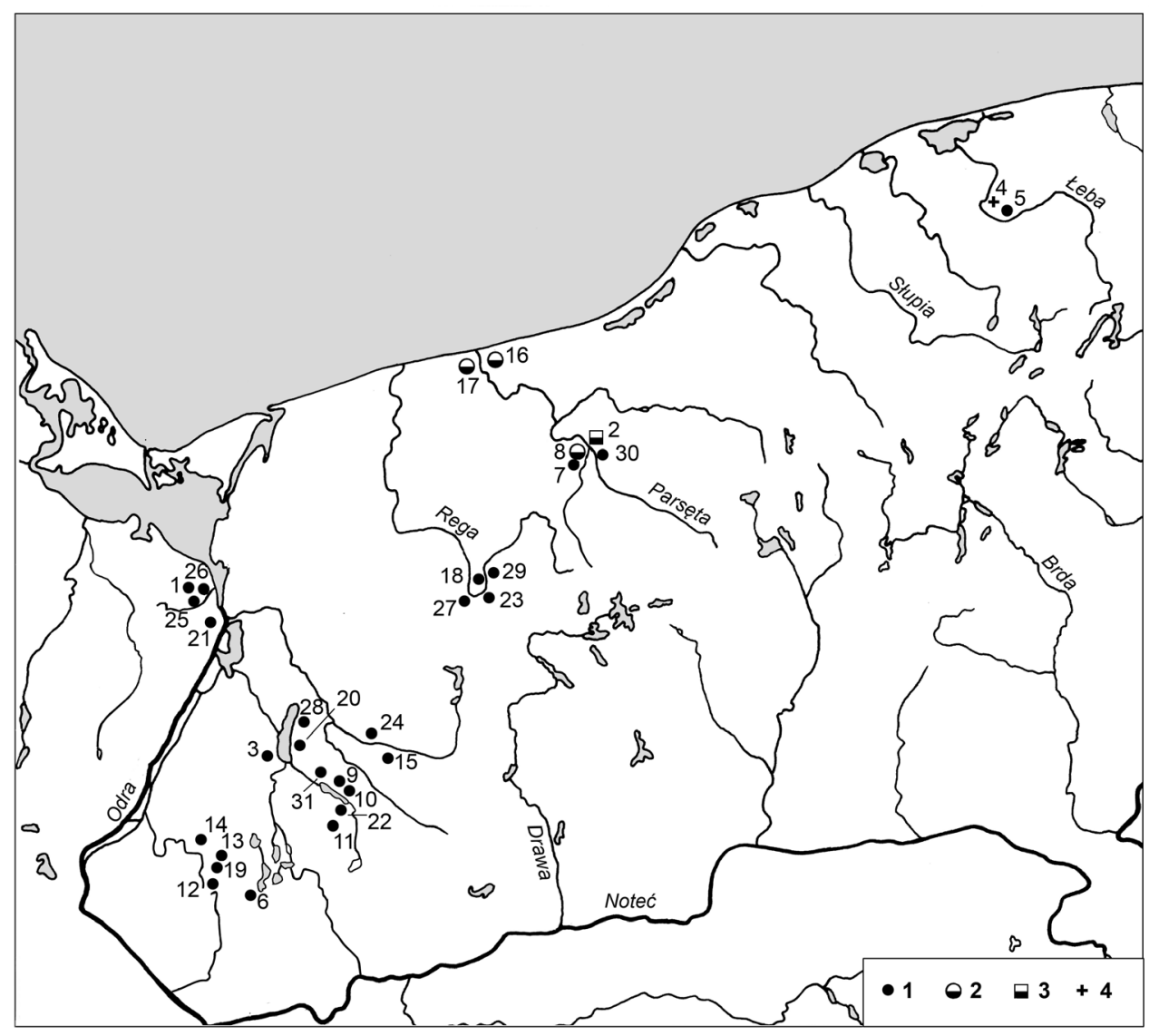

Ryc. 1. Najstarsze ślady osadnictwa wczesnośredniowiecznego na Pomorzu Zachodnim (zob. katalog). Rys. E. Pawlak

tywnie bogatej sieci osadnictwa otwartego otaczającego tę warownię (por. Cnotliwy 1999, s. 74, ryc. 2; Machajewski 2017, s. 279, ryc. 6).

Natomiast cmentarzysko w Czarnówku (katalog - nr 4), gdzie wśród 34 grobów pochodzących z okresu od VII do XI w. stwierdzono około 14 płaskich pochówków popielnicowych i jamowych wyposażonych w naczynia ceramiczne ręcznie lepione typu Dziedzice datowane na VII i 1. połowę VIII w., wyjątkowo w drobne przedmioty codziennego użytku (por. Wadyl 2015, s. 49-51, gdzie autor opracowania używa określenia ceramika typu Suckow). Fenomen tej nekropoli, zwłaszcza pochówków z VII-VIII w. (I faza użytkowania cmentarzyska), polega na tym, że jest pierwszym tego rodzaju znaleziskiem w uznawanej dotychczas za bezpochówkową strefę sepulkralną z początków wczesnego średniowiecza wg Heleny Zoll-Adamikowej (1979. Por. Dulinicz 2001, s. 200, ryc. 217), co w świetle wyników badań 
tego cmentarzyska utraciło raczej swoje uzasadnienie. Zresztą, podobne pochówki odkryto w ostatnim czasie także w innych regionach tej strefy bezpochówkowej, zwłaszcza w Meklemburgii (por. Dulinicz 2001, s. 199-200, ryc. 217). Wielkość i rozplanowanie cmentarzyska w Czarnówku, ze względu na sygnalizowane w tym artykule podobieństwo ceramiki typu Dziedzice do ceramiki znajdowanej w odkrywanych „,po sąsiedzku” grobach skandynawskich, a tym samym zgłaszana wątpliwość co do pierwotnej liczby grobów z najwcześniejszych etapów wczesnego średniowiecza, ale także zniszczenie przynajmniej części obiektów ze względu na ich płytkie zaleganie, pozostaje trudna do oszacowania. Warto w tym miejscu odnotować, że w odległości około $0,2 \mathrm{~km}$ od cmentarzyska funkcjonowała osada otwarta (Czarnówko, stan. 21) w czasie odpowiadającym najwcześniejszemu okresowi wczesnego średniowiecza (Wadyl 2015, s. 57).

W wyznaczonym układzie na Pomorzu Zachodnim pozostałości po najwcześniejszym osadnictwie wczesnośredniowiecznym uwagę zwraca sposób ich rozmieszczenia. W ujęciu makroregionalnym owo osadnictwo skupiało się przynajmniej w czterech regionach: (a) między dolną Odrą a Iną; (b) w dorzeczu górnej Regi; (b) w dorzeczu dolnej i środkowej Parsęty; (c) w dorzeczu dolnej Łeby (ryc. 1). Niezależnie od regionu osadnictwo lokowano na terasach nadzalewowych lub na niewielkich wzniesieniach znajdujących się na terasach zalewowych, układających się wzdłuż dobrze rozwiniętych pradolin rzek zazwyczaj spływu dobałtyckiego, tworząc w ich obrębie niewielkie skupiska osadnicze. Trudno, z uwagi na stan badań terenowych, przeprowadzać gradację funkcji poszczególnych osad. W jakim zakresie ich położenie było efektem czynnika gospodarczego, społecznego i politycznego, pozostaje pytaniem ciągle bez jasnej odpowiedzi. Można jedynie suponować o niektórych elementach tych czynników wpływających na wybór miejsca dla rozwoju osadnictwa w konkretnej rzeczywistości dziejowej (por. Latałowa 2017, s. 18-22). Jednym z ważniejszych czynników były warunki siedliskowe umożliwiające rozwój ekstensywnej gospodarki zwłaszcza rolnej i hodowlanej, w niewielkim zakresie leśnej i wodnej. Innym były sprzyjające okoliczności do utrzymywania kontaktów wymiennych. W jakimś stopniu owe czynniki wywierały wpływ na proces reorganizacji społecznej i politycznej konkretnej grupy kulturowej dążącej do nawiązania okazjonalnych lub stałych kontaktów ze społecznościami obcymi, a nawet zajmowania ich terenów osadniczych. W konkretnej sytuacji początków wczesnego średniowiecza ważną rolę mogła odgrywać także tradycja w wykorzystywaniu konkretnych regionów/szlaków, poprzez które upowszechniano wiedzę o ich wartościach gospodarczych i funkcji w kontaktach wymiennych.

Próbując wskazać tylko na niektóre z cech kulturowych społeczności Pomorza Zachodniego w najwcześniejszych etapach wczesnego średniowiecza, zauważa się, że zaczęło się ono pojawiać w regionach, gdzie jeszcze we wczesnej fazie okresu wędrówek ludów rozwijało się osadnictwo ludności grupy dębczyńskiej (Machajewski, w druku). W przestrzeni migroregionalnej zajmowano te same tereny lub sąsiadujące $\mathrm{z}$ nimi. Odzwierciedla to sytuacja zwłaszcza w dorzeczu środkowej 
Parsęty i górnej Regi, w mniejszym zakresie między dolną Odrą a Iną, gdzie osadnictwo starożytne uległo nieco wcześniej rozproszeniu (Łosiński 1982, s. 29, ryc. 5; Parczewski 1988, s. 20-21, ryc. 1-2; Machajewski 2017, s. 278-279, ryc. 5-6; Latałowa 2017, s. 18). Wyjątkowa natomiast była sytuacja w dorzeczu dolnej Łeby, gdzie owo osadnictwo pojawiło się w sąsiedztwie skupiska kilku niewielkich cmentarzysk skandynawskich opuszczonych u schyłku 1. połowy VI wieku (Machajewski 2017, s. 286, ryc. 9). Czy wybór tych miejsc był efektem wyszukiwania jedynie podobnych siedlisk umożliwiających rozwój gospodarki ekstensywnej, tak charakterystycznej dla społeczności żyjącej na przełomie starożytności i wczesnego średniowiecza, czy także próbą nawiązywania kontaktów z miejscową społecznością?

Inspiracja do nawiązywania tych kontaktów w konsekwencji mogła wpisywać się w dzieje prowadzonych już przez miejscowe społeczności kontaktów wymiennych (por. Ł. Leciejewicz 1976, s. 42-45). Na Pomorzu niemal zawsze zauważalne były powiązania ze Skandynawią, w węższym zakresie ze społecznościami zamieszkującymi południowo-zachodnią i południowo-wschodnią strefę Morza Bałtyckiego. We wczesnej fazie okresu wędrówek ludów tradycje kontaktów wymiennych, dokumentowane nawet faktem przemieszczania się ludności ze Skandynawii na Pomorze, były ewidentne, przy czym część owej społeczności pozostawała tutaj, inna kierowała się na jeszcze dalej położone regiony (Machajewski 1992a, s. 79-92; Machajewski 2012, s. 206-222; Shuster 2015, s. 29-31). Od 2. połowy V w. po przełom VI i VII w. rozwijano je ze społecznościami zamieszkującymi tereny Niżu Polskiego, zwłaszcza północnej Wielkopolski i Kujaw (Machajewski 2017, s. 288; Rudnicki 2017, s. 52-57). Niewykluczone, że w nurt tych kontaktów wpisała się społeczność wczesnośredniowieczna, a jednym z motywów dla nich, rozwijanych zwłaszcza wzdłuż Regi, Parsęty i prawdopodobnie Łeby, a dalej za pośrednictwem pradoliny Noteci z pozostałymi terenami Niżu Polskiego, mogły stanowić wartości złóż solankowych zalegające w dolnej Parsęcie oraz w okolicy Wapna w Wielkopolsce i na Kujawach. Czy w nurt tych kontaktów wpisała się społeczność już wczesnośredniowiecza lub czy była znana jej jedynie tradycja możliwości ich rozwijania wzdłuż wspomnianych rzek? Niewykluczone, że następstwem tych zdarzeń, niezależnie od przyjętej tezy o rodzaju tych kontaktów, mogło być pojawienie się wczesnośredniowiecznego osadnictwa otwartego w pradolinie Parsęty i Regi, a następnie wygradzanie terenów pod przyszłe grodziska, czego efektem było grodzisko w Białogardzie.

Natomiast zasiedlanie terenów między dolną Odrą i Iną, jakkolwiek niewykluczone, że mogło być ono inspirowane także podobnymi przesłankami do wcześniej zasygnalizowanych, lecz odzwierciedlało proces zajmowania terenów raczej już wcześniej opuszczonych. Z podobnymi wydarzeniami spotykamy się zapewne w sąsiedniej części Wielkopolski północno-zachodniej i na Ziemi Lubuskiej (por. Godłowski 1981, s. 99, ryc. 24; Parczewski 1988, s. 20-21, ryc. 1-2; Mączyńska 1999, s. 38, mapa 1; Mączyńska 2007, s. 372, mapa 4). Czy owe wydarzenia 
pozostawały ze sobą w związku, nie wiadomo, i jest to pytanie jeszcze bez jasnej odpowiedzi. Ten jednak kierunek interpretacji po części potwierdzają wyniki badań palinologicznych uzyskane w tych regionach (Latałowa 2017, s. 20, ryc. 3).

Tak więc ujawnione na Pomorzu Zachodnim osadnictwo łączone z najwcześniejszymi etapami wczesnego średniowiecza (VI-VII w.) mogło być następstwem kilku odmiennych zdarzeń, mających miejsce w różnych częściach tego obszaru. Hierarchizacja tych zdarzeń jest niejasna. Uwagę zwraca jednak sytuacja w dorzeczu Parsęty, Regi i Łeby, dokumentująca, wbrew dawniejszym sugestiom, coraz bliższe następstwo kulturowo-osadnicze społeczności ze schyłku starożytności i początku średniowiecza (por. Dulinicz 2001, s. 207).

Podsumowując, zbiór dotychczas ujawnionych informacji archeologicznych o początkach osadnictwa wczesnośredniowiecznego na Pomorzu Zachodnim tworzy jednorodny w ogólnej wymowie zespół danych, który tylko w szczegółowej konfrontacji ze źródłami ze schyłku starożytności i rozwiniętych etapów wczesnego średniowiecza, dopełniony informacjami pozaarcheologicznymi, może stanowić podstawę do szczegółowego wyjaśnienia procesu początków owego osadnictwa $\mathrm{w}$ tym regionie.

\section{ANEKS}

\section{Wykaz najstarszych śladów osadnictwa wczesnośredniowiecznego na Pomorzu Zachodnim (zob. ryc. 1)}

1. Bezrzecze, pow. Police, stan. 1 - osada (bad. powierzchniowe): VI-VII w.

2. Białogard, pow. Białogard, stan. 1 - grodzisko (bad. wykopaliskowe): VII-VIII w. (najstarsza faza)

3. Bielice, pow. Pyrzyce, stan. 10 - osada (bad. powierzchniowe): VI-VII w.

4. Czarnówko, pow. Lębork, stan. 5 - cmentarzysko (bad. wykopaliskowe): VII-VIII w. (?)

5. Czarnówko, pow. Lębork, stan. 21 - osada (bad. wykopaliskowe): VII-VIII w. (?)

6. Derczewo, pow. Myślibórz, stan. 3 - osada (bad. wykopaliskowe): VI-VIII w.

7. Dębczyno, pow. Białogard, stan. 10 - osada (bad. wykopaliskowe): VI-VIII w.

8. Dębczyno, pow. Białogard, stan. 38 - osada (bad. wykopaliskowe): VII-VIII w. (?)

9. Dobropole Pyrzyckie, pow. Pyrzyce, stan. 12 (bad. powierzchniowe): VI-VII w.

10. Dobropole Pyrzyckie, pow. Pyrzyce, stan. 14 (bad. powierzchniowe): VI-VII w.

11. Dziedzice, pow. Myślibórz, stan. 4 (bad. wykopaliskowe): VI-VII w.

12. Golenice, pow. Myślibórz, stan. 3 (bad. wykopaliskowe): VI-VII w.

13. Kosin-Pyrzyce, pow. Pyrzyce, stan. 10 (bad. wykopaliskowe): VI-VII w.

14. Kozielice, pow. Pyrzyce, stan. 8 (bad. powierzchniowe): VI-VII w.

15. Krępcewo, pow. Pyrzyce, stan. 3 (bad. powierzchniowe): VI-VII w.

16. Kołobrzeg-Wyspa Solna, pow. Kołobrzeg, stan. 2 (bad. wykopaliskowe): VII-VIII w.

17. Kołobrzeg, pow. Kołobrzeg, stan. 3 (bad. wykopaliskowe): VII-VIII w.

18. Łobżany, pow. Łobez, stan. 1 (bad. wykopaliskowe): VI-VII w.

19. Letnin, pow. Pyrzyce, stan. 15 (bad. powierzchniowe): VI-VII w.

20. Obryta, pow. Pyrzyce, stan. 7 (bad. powierzchniowe): VI-VII w.

21. Przecław, pow. Szczecin, stan. 1 (bad. powierzchniowe): VI-VII w.

22. Przelewice, pow. Pyrzyce, stan. 10 (bad. powierzchniowe): VI-VII w.

23. Rynowo, pow. Łobez, stan. ? (bad. powierzchniowe): VI-VII w. 
24. Strachocin, pow. Stargard, stan. 4 (bad. powierzchniowe): VI-VII w.

25. Szczecin-Krzekowo, pow. Szczecin, stan. 3 (bad. powierzchniowe): VI-VII w.

26. Szczecin-Niemierzyn, pow. Szczecin, stan. ? (bad. powierzchniowe): VI-VII w.

27. Święciechowo, pow. Łobez, stan. 3 (bad. powierzchniowe): VI-VII w.

28. Wierzchląd, pow. Stargard, stan. 3 (bad. powierzchniowe): VI-VII w.

29. Worowo, pow. Łobez, stan. 5 (bad. powierzchniowe): VI-VII w.

30. Wygoda, pow. Białogard, stan. 6/B (bad. wykopaliskowe): VI-VII w.

31. Żuków, pow. Stargard, stan. 2 (bad. powierzchniowe): VI-VII w.

\section{BIBLIOGRAFIA}

Cnotliwy E. 1982, Białogard. Gród wczesnopolski, Koszalin.

- 1986, Chronologia ceramiki i nawarstwień wczesnośredniowiecznego Białogardu, w: Problemy chronologii wczesnośredniowiecznej na Pomorzu Zachodnim, Warszawa, s. 146-169.

- 1999, Biatogard i okolice we wczesnym średniowieczu, B. Polak (red.), Białogard 1299-1999. Studia $z$ dziejów miasta, Koszalin-Białogard, s. 71-93.

Dulinicz M. 2001, Kształtowanie się Stowiańszczyzny Pólnocno-Zachodniej. Studium archeologiczne, Warszawa.

Filipowiak W. 1966, Pomorze Zachodnie w okresie wczesnośredniowiecznym, w: Tysiąc lat nad Odra i Battykiem, Szczecin, s. 71-118.

Godłowski K. 1981, Okres wędrówek ludów na Pomorzu, „Slavia Antiqua”, t. 10, s. 65-129.

Historia Pomorza 1972, Historia Pomorza, t. 1, cz. 1, G. Labuda (red.), Poznań, s. 51-81.

Latałowa M. 2017, Przyrodnicze ślady przemian osadniczy między Odra a Wisła w I tysiacleciu po Chr., w: Barbarzyńskie tsunami. Okres wędrówek ludów w dorzeczu Ody $i$ Wisty, Warszawa-Szczecin, s. 17-23.

Leciejewicz L. 1960, Wczesnośredniowieczny Kołobrzeg, „Slavia Antiqua”, t. 7, s. 107-392. 1976, Stowiańszczyzna zachodnia, Wrocław-Warszawa-Kraków-Gdańsk.

Łęga W. 1930, Kultura Pomorza we wczesnym średniowieczu na podstawie wykopalisk, Torun.

Łosiński W. 1972, Początki wczesnośredniowiecznego osadnictwa grodowego w dorzeczu dolnej Parsęty (VII-X/XI w.), Wrocław-Warszawa-Kraków-Gdańsk.

- 1981, Aktualne problemy badań archeologicznych nad wczesnym średniowieczem Pomorza, „Pomorania Antiqua", t. 10, s. 131-154.

- 1981, Osadnictwo plemienne Pomorza (VI-X wiek), Wrocław-Warszawa-Kraków-Gdańsk-Łódź.

- 1990, Stan i potrzeby badań nad wczesnym średniowieczem na Pomorzu Zachodnim, Z. Kurnatowska (red.), Stan i potrzeby badań nad wczesnym średniowieczem w Polsce, Poznań-Wrocław-Warszawa, s. 23-49.

- 2008, Pomorze Zachodnie we wczesnym średniowieczu, Poznań.

Łosiński W., Rogosz R. 1983, Zasady klasyfikacji i schemat taksonomiczny ceramiki, E. Cnotliwy, L. Leciejewicz, W. Łosiński (red.), Szczecin we wczesnym średniowieczu. Wzgórze Zamkowe, Wrocław-Warszawa-Kraków-Gdańsk-Łódź, s. 202-244.

- 1986, Metody synchronizacji warstw kulturowych wczesnośredniowiecznych obiektów wielowarstwowych na podstawie analizy ceramiki ze Szczecina, w: Problemy chronologii ceramiki wczesnośredniowiecznej na Pomorzu Zachodnim, Warszawa, s. 9-50.

Machajewski H. 1981, Sytuacja osadnicza w dorzeczu dolnej Parsęty w czasie od I w. p.n.e. do V/VI w. n.e., „Fontes Archaeologici Posnanienses”, t. 30, s. 26-37.

- 1992a, Z badań nad chronologia dębczyńskiej grupy kulturowej w dorzeczu Parsęty, Poznań.

- 1992b, Skandynawskie elementy kulturowe na Pomorzu Zachodnim w okresie wędrówek ludów (2 polowa IV w.-początek VI w.), „Przegląd Archeologiczny”, t. 40, s. 71-96.

- 2001, Profesor Jan Żak: zagadnienie kontynuacji i dyskontynuacji u schyłku starożytności i na poczatku wczesnego średniowiecza w świetle badań na Pomorzu Zachodnim, D. Minta-Tworzowska, W. Rączkowski (red.), Archeologia, paradygmat, pamięć, Poznań, s. 91-106. 
- 2012, Wprowadzenie do problematyki kulturowej zabytków z okresu wpływów rzymskich $i$ wczesnej fazy okresu wędrówek ludów (I-V/VI wiek), K. Kowalski, D. Kozłowska-Skoczka (red.), Zaginione - ocalone. Szczecińska kolekcja starożytności pomorskich, Szczecin, s. 203-222.

- 2017, Pradolina środkowej Parsęty u schytku starożytności i na początku wczesnego średniowiecza (II/III w.-VII/VIII w.), w: Pradoliny pomorskich rzek. Kontakty kulturowe $i$ handlowe społeczeństw w pradziejach i wczesnym średniowieczu, Gdańsk, s. 273-292.

- w druku, Osada w Dębczynie, powiat białogardzki, stanowisko 6. Ze studiów nad obliczem kulturowo-osadniczym Pomorza Zachodniego u schytku starożytności, Gdańsk.

Mączyńska M. 1999, Schyłkowa faza kultury przeworskiej, A. Kokowski (red.), Kultura przeworska, t. 4, Lublin, s. 25-53.

- 2007, Zmierzch kultury wielbarskiej - czego nie wiemy?, M. Fudziński, H. Paner (red.), Nowe materialy i interpretacje. Stan dyskusji na temat kultury wielbarskiej, Gdańsk, s. 365-401.

Parczewski M. 1988, Początki kultury wczesnosłowiańskiej w Polsce. Krytyka i datowanie źródeł archeologicznych, Wrocław-Warszawa-Kraków-Gdańsk-Łódź.

- 2017, Idzie nowe. Pierwsi Stowianie na ziemiach Polski, w: Barbarzyńskie tsunami. Okres wędrówek ludów w dorzeczu Odry $i$ Wisty, Warszawa-Szczecin, s. 59-65.

Rudnicki M. 2017, Wandalskie ostatki. Germanie na ziemiach Polski na przełomie starożytności i średniowiecza (V-VII w.), w: Barbarzyńskie tsunami. Okres wędrówek ludów w dorzeczu Odry $i$ Wisty, Warszawa-Szczecin, s. 51-57.

Schuster J. 2015, Przybysze ze Skandynawii - mate cmentarzysko z okresu wędrówek ludów, J. Andrzejowski (red.), Czarnówko, stan. 5. Cmentarzysko z późnej starożytności na Pomorzu, cz. 1. Monumenta Archaeologica Barbarica, Series Gemina 5, Lębork, Warszawa, s. 15-42.

Sikorski A. 1982, Osada z najwcześniejszej fazy wczesnego średniowiecza w Dębczynie (stan. 10) na Pomorzu Środkowym, „Slavia Antiqua”, t. 34, s. 247-249.

- 1984, Wyniki badań na osadzie wczesnośredniowiecznej w Wygodzie, stan. 6 B, gm. Białogard w 1983 roku, „Koszalińskie Zeszyty Muzealne”, t. 14, s. 29-41.

- 1986, Problem ceramiki typu Dziedzice w świetle badań w Dębczynie, woj. Koszalin, „Folia Praehistorica Posnaniensia", t. 2, s. 279-302.

Strobin A., Machajewski H. 2017, Cmentarzysko z okresu wędrówek ludów w Brzynie, pow. pucki, stanowisko 7. Ze studiów nad okresem wędrówek ludów na Pomorzu Wschodnim, w: Orbis Barbarorum. Studia ad Archaeologiam et Baltorum Temporibus Imperii Romani Pertinentia Adalberto Nowakowski Dedicata. Monumenta Archaeologica Barbarica, series Gemina, t. 6, Warszawa-Schleswig, s. 549-574.

Zoll-Adamikowa H. 1979, Wczesnośredniowieczne cmentarzyska ciałopalne Stowian na terenie Polski, cz. 1. Źródła, Wrocław-Warszawa-Kraków-Gdańsk.

Żak J. 1985, O kontynuacji i dyskontynuacji spotecznej i kulturowej na ziemiach nadodrzańskich i nadwiślańskich w V-VI w. n.e., „Folia Praehistorica Posnaniensia”, t. 1, s. 85-108. 